
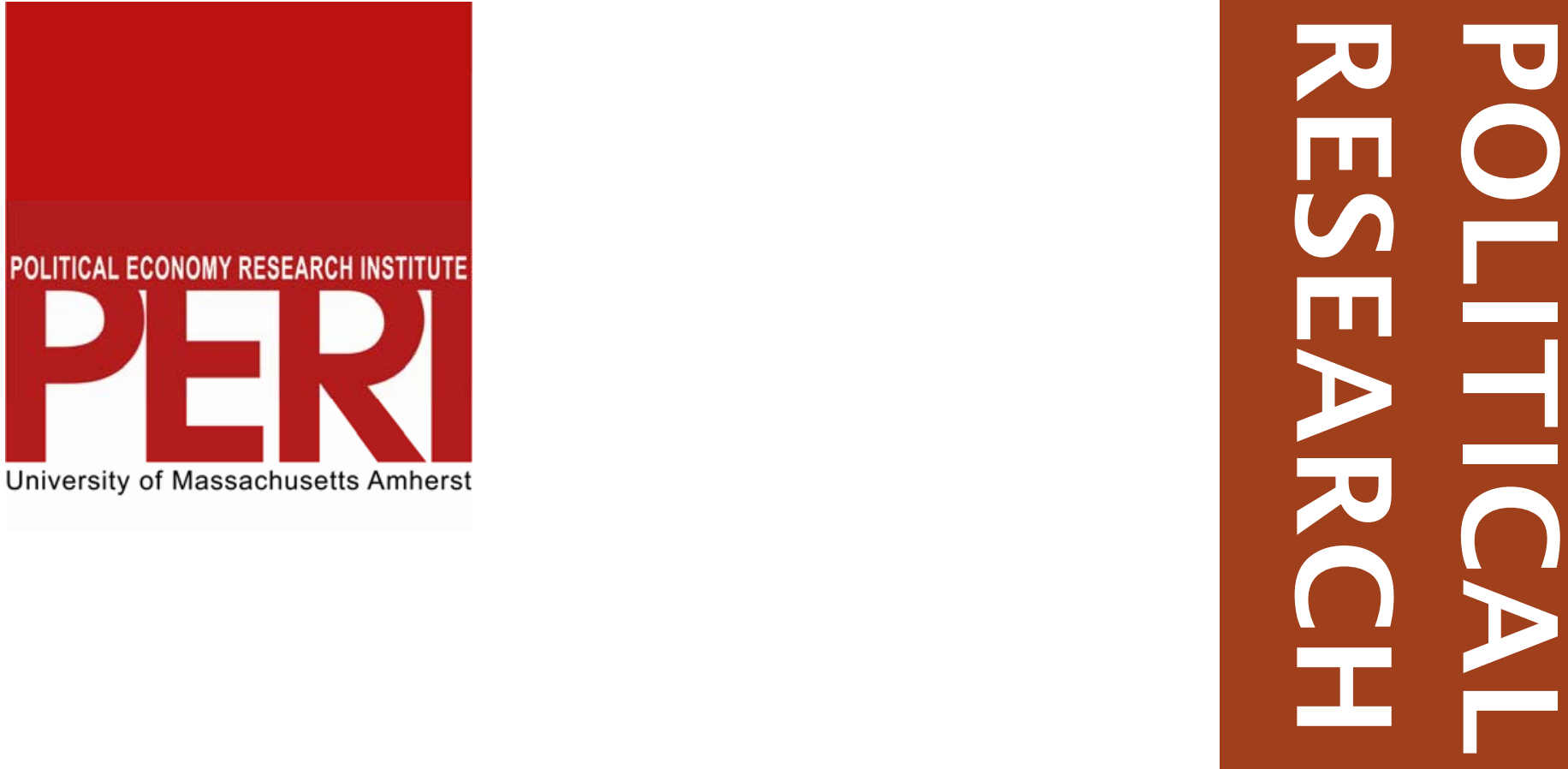

Bargaining Power, Distributional Equity and the Challenge of Off-Shoring

\author{
James Burke \& Gerald Epstein
}

January 2007

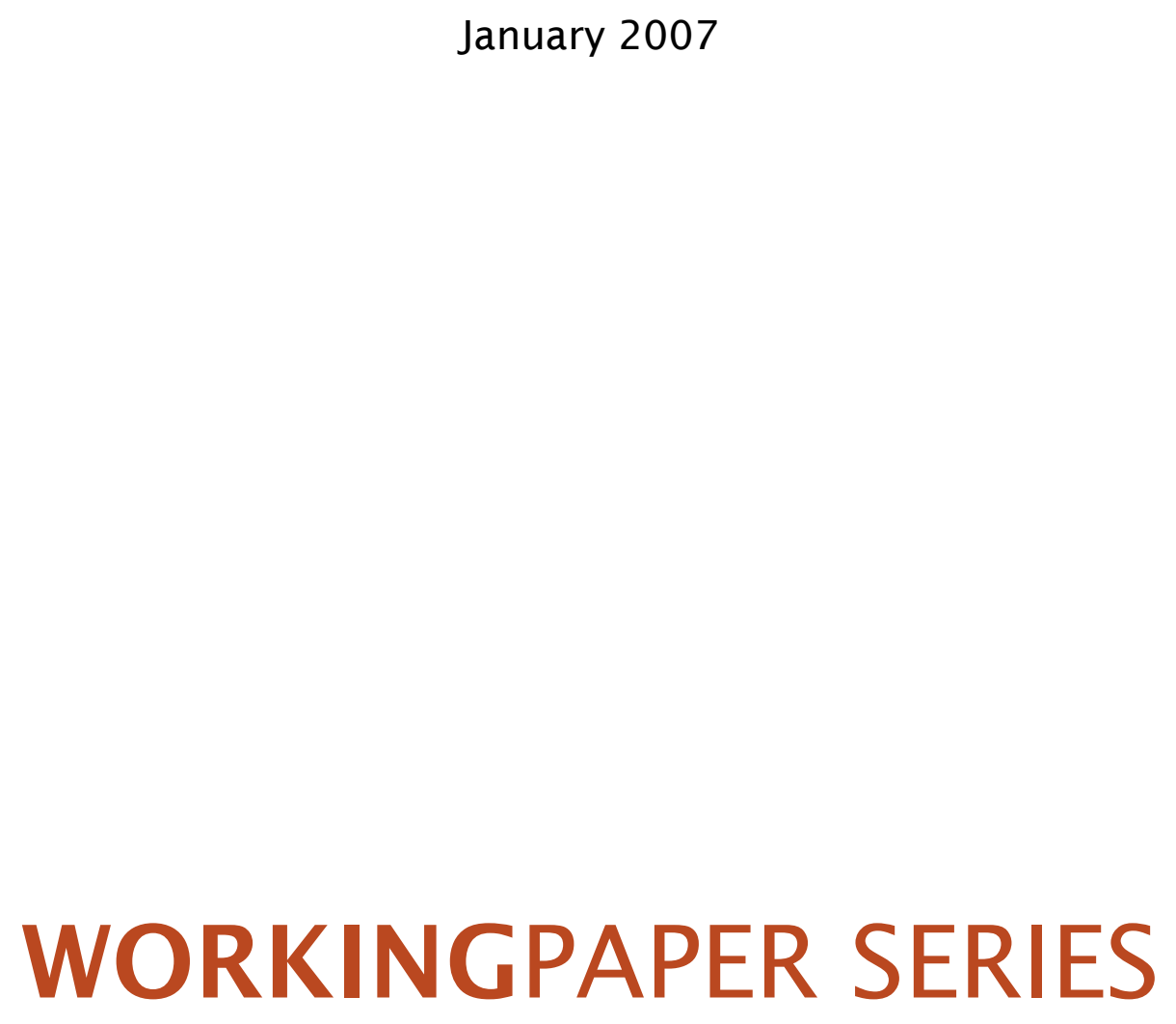

Gordon Hall

418 North Pleasant Street

Amherst, MA 01002

Phone: 413.545 .6355

Fax: 413.577 .0261

peri@econs.umass.edu www.peri.umass.edu 


\title{
Bargaining Power, Distributional Equity and The Challenge of Off-Shoring
}

\author{
James Burke and Gerald Epstein*
}

January, 2007

The authors are at Mount Holyoke College and at the Economics Department and Political Economy Research Institute (PERI) of the University of Massachusetts, respectively. This is a radically shortened and revised version of a paper prepared for the Conference on "The New Global Division of Labor: Winners and Losers from Off-shoring”, Center for Global Initiatives, Mount Holyoke College, March 3-4, 2006. Many thanks to Eva Paus for her extremely helpful comments and suggestions. The authors also thank Arjun Jayadev, Minsik Choi, Derek Weener and Elissa Braunstein for help. The Political Economy Research Institute (PERI) provided research support. All errors are ours, of course. 


\begin{abstract}
When off-shoring occurs in a context of high levels of aggregate demand, adequate tax levels and effective rules which allow governments to coordinate, then it may indeed have a positive impact on nations and communities. On the other hand, when it occurs in a context of low levels of aggregate demand and destructive economic and political competition in the absence of effective rules, then offshoring can have a significant negative impact on workers in both home and host countries. However, offshoring itself, and globalization more generally reduce citizens' bargaining power making it difficult for the majority of them to gain from off-shoring, and they undermine the ability of governments to provide the social investments that would enhance the ability of these countries to compete successfully in the global economy. Proponents in the U.S. of a more efficient and equitable approach to off-shoring should support a moratorium on all future trade and investment agreements until solutions are implemented to the taxation, social investment and aggregate demand problems we have identified. In short, the presumption should be that globalization should NOT be allowed to undermine the bargaining power of citizens or the social investments of society. And until globalization can proceed without doing so, future movement in that direction should be halted.
\end{abstract}


Off-shoring, like globalization generally, is not inherently good or bad. Its effects will strongly depend on the overall national and international context within which it occurs. Here we focus on three aspects of the overall context which are especially important in determining the impact of off-shoring: the state of both national and global aggregate demand (AD), the nature of the domestic and international tax rules, and the nature of domestic and international coordination of policies. These three factors have a significant impact on the effects of off-shoring and related phenomena on the economy, and in particular on their effects on wages, inequality and the level of unemployment and underemployment.

There are many channels through which these factors ultimately affect the distributional and over-all macroeconomic effects of off-shoring, but here we focus on two major mechanisms: 1) their impact through the bargaining channel, and 2) their impact through the social investment channel. By bargaining channel we mean the impact of off-shoring on the bargaining power of workers and governments relative to corporations. And by the social investment channel, we mean the impact of off-shoring on the ability of governments to provide social goods such as infrastructure, education and health benefits. We argue that not only the level and growth rate of off-shoring can affect its distributional and macroeconomic impacts, but that the threat of off-shoring can have potent affects as well. $^{1}$

When off-shoring occurs in a context of high levels of aggregate demand, adequate tax levels and effective rules which allow governments to coordinate, then it may indeed have a positive impact on nations and communities. On the other hand, when it occurs in a context of low levels of aggregate demand and destructive economic and political competition in the absence of effective rules, then offshoring can have a significant negative impact on workers in both home and host countries. These problems reduce citizens' bargaining power making it difficult for the majority of them to gain from off-shoring, and they undermine the ability of governments to provide the social investments that would enhance the ability of these countries to compete successfully in the global economy.

Economists must confront the resulting bargaining and social investment problems directly, if policies to reduce the distributional and macroeconomic costs of off-shoring and related phenomena are going to be implemented. The need for an increase in the bargaining power of workers and citizens to demand ameliorative policies and a larger capacity of governments to provide such policies must be part of any serious discussion of these issues. Up to now, however, most economists have ignored these issues.

\footnotetext{
${ }^{1}$ See Crotty, Epstein and Kelly (1998), Rodrik (1997), and Burke and Epstein (2001) for elaborations of these arguments with respect to globalization generally and foreign direct investment in particular.
} 


\section{The Impact of Off-Shoring on Employment in the US}

In this section we examine the scope and employment impact of off-shoring in US manufacturing. Empirical evidence supports the idea that off-shoring has had negative impacts on employment in U.S. manufacturing. Our findings provide evidence that off-shoring has distributional implications through the bargaining channel, and, moreover, that aggregate demand can have an important impact on the direction and strength of those impacts.

The increase in offshoring together with the negative employment impact in U.S. manufacturing provides the needed context for understanding the importance of the bargaining channel between workers and firms that we return to in the following sections of the paper.

The growing literature on the impact of offshoring on employment and wages in the U.S. has not generated a consensus. The prima facie evidence would suggest that increased MNC expansion abroad has a negative impact on U.S. domestic employment. For example, between 1977 and 1999, U.S. multinational corporations reduced U.S. domestic employment in manufacturing by 3 million, while expanding employment in low-income countries (Burke and Epstein, 2002, Harrison and McMillan, 2006, 4). Yet, a number of recent studies suggest that U.S. MNCs create more domestic employment, when they invest abroad. ${ }^{2}$

Harrison and McMillan (2006) argue that the inconsistency among these different studies is mostly resolved, when one distinguishes between MNC activities in low income countries and in high income countries. For MNCs with affiliates in low income countries, the contraction in U.S. manufacturing employment has been accompanied by an increase in employment in foreign affiliates abroad. Harrison and McMillan $(2006,35)$ also find a big employment impact of investment abroad by U.S. multinational corporations. ${ }^{3}$ A 10 percent increase in the capital stock in high or low income affiliates is associated with a decline in US employment of between .1 and 1.8 percent. And since the capital stock in affiliates has increased by over 100 percent between 1982 and 1999, "this diversion of investment towards affiliates resulted in a decline of up to 18 percent in US manufacturing employment" (Harrison and McMillan, 2006, 35).

Other authors have estimated the impact of offshoring on U.S. employment in manufacturing by using the ratio of imported intermediate goods relative to total intermediate input purchases as an indicator of off-shoring activity in an industry sector (e.g., Feenstra and Hanson, 1999, and Campa and Goldberg, 1997). When goods produced abroad replace intermediate stages of production at home, the flow of imports of intermediate goods increases across country borders.

\footnotetext{
${ }^{2}$ See Harrison and McMillan (2006) for a recent review; see also, for example, Mankiw and Swagel (2006).

${ }^{3}$ This is consistent with earlier work by James Burke (1997).
} 
Tracking the share of imports in total purchases of intermediate manufacturing goods allows us to detect changes in the scope of off-shoring in US manufacturing over time. ${ }^{4}$

Feenstra and Hanson (1999) find that imported intermediate goods increased from 5.3 percent of total intermediate purchases for U.S. manufacturing industries in 1972 to 7.3 percent in 1979 and 12.1 percent in 1990. Using a narrower measure of intermediate goods, Campa and Goldberg (1997) find that imported inputs have increased from 4.1 percent of total intermediate goods in 1975 to 6.2 percent in 1985, and 8.2 percent in 1995 for U.S. manufacturing industries.

Our own research (Burke and Epstein 2006) shows that the share of imported intermediate inputs in total intermediate inputs is much higher. Between 1987 and 2003, the share of imported inputs in the whole manufacturing sector rose from 12.4 percent to 22.7. Our results also indicate that the growth rate of the imported input share accelerated during this period. Of the total increase of 10.4 percentage points in the import share of inputs, the period 1987 - 1992 accounts for 1.5 percentage points, the period 1992 - 1997 accounts for 3.8 percentage points, and the latest six-year period, 1997 - 2003, accounts for 5.0 percentage points. We found an acceleration of the growth of the imported input share in 13 of the 19 manufacturing industry groups.

Because we are interested in the links between off-shoring and industry employment at home, we also examined which industries produce these intermediate inputs, rather than, as before, which industries use them. The reason for this is simple: we expect the demand for production and workers to be linked to the extent to which the intermediate goods a particular industry produces are displaced by imported inputs. We found that for every industry group and for the manufacturing sector as a whole, the share of imports in total inputs produced has risen over the time period. For all manufacturing, the share of imported inputs rose from 19.1 percent in 1998 to 22.8 percent in 2003.

Following a more gradual downward trend since the late 1970s, employment in U.S. manufacturing fell by 3 million jobs, 18 percent, between 1998 and 2003 to reach its lowest level in over half a century. Our research suggests that the increase in offshoring has contributed to that decline. Table 1 shows data on employment declines as well as the import ratio of intermediate goods produced by the nineteen industry groups that make up the manufacturing sector for the period from 1998 to 2003 . Employment fell in all nineteen industry groups during these years, although the rates of employment decline varied greatly across industries. The Apparel and Leather Products group - an industry

\footnotetext{
${ }^{4} \mathrm{~A}$ basic assumption of this method is that the import share of the commodity when it is used as an intermediate good in each particular industry is the same as the import share of the commodity in the economy as a whole as calculated from the $\mathrm{I} / \mathrm{O}$ accounts.
} 
that lost over half of its employment in the years from 1998 to 2003 - appears to be the most highly affected by off-shoring with the ratio of imported inputs in total inputs produced by the group reaching over 60 percent.

[Table 1 about here]

The statistical results in Burke and Epstein (2006) support a link between offshoring and employment losses. Changes in demand, technological processes, trade and off-shoring are each associated with changes in manufacturing industry employment in expected ways. Increases in off-shoring are shown to have a modest effect in reducing employment in manufacturing industries, while a decline in domestic and foreign demand corresponds to large decreases in employment over the period. As we will discuss in detail below, these results suggests that measures to expand aggregate demand at home and abroad can play an important role in ameliorating the negative impacts of offshoring in manufacturing.

A newer phenomenon of increasing concern, but also of less clear dimensions, is the rise of services offshoring. There is enormous uncertainty about the current extent of services offshoring and its future potential (see, for example Abugattas in this volume). But several authors have made compelling arguments that it is likely to become much more widespread over the next ten to twenty years than it is today. Alan Blinder (2005) argues that 'impersonal services' will become increasingly tradable, placing higher paid US, European and Japanese workers in direct competition with much lower paid workers in developing countries, especially those who are able to communicate in Western languages. These pressures will increasingly put jobs and wages at risk in the richer countries and will require significant labor market adjustments and interventions by governments, especially in the area of education and social safety nets.

\section{Bargaining, Coordination, and the Impact of Off-Shoring}

The previous discussion suggests that off-shoring has been increasing, that it has had a significant negative impact on manufacturing employment and that, in the service sector, there are reasons to believe that a significant number of workers will be affected negatively in the future.

In discussions of these issues, it is common now to blithely note that there will be 'winners' and 'losers' from international trade. To do so is seen as a major advance over earlier discussions which claimed that everyone is a winner from international trade. However, identifying the potentially negative impact of offshoring as 'only' a distributional problem within an overall context of increased efficiency and productivity fundamentally underestimates the potential social costs. The deep and long-lasting individual costs associated with lay-offs are much larger than commonly understood, even when workers are re-employed at 
similar wages (Uchitelle 2006). But, as a number of economists have shown (e.g. Kletzer 2002) former U.S. manufacturing workers typically are re-employed at significantly lower wages.

In light of this, are we really sure that off-shoring increases the size of the economic pie? As Keynes stressed in his discussion of unemployment, involuntary job loss is not only a personal and distributional problem: it represents a fundamental loss to community and society. This is true even in the event that job loss is temporary. And, in fact, the dislocations associated with broad structural changes are permanent and have much greater costs in terms of obsolescence of skills and disruption of community. Of course, not all change, even change that has costs, is on balance bad. But, as Uchitelle effectively points out, economists have been lax in trying to estimate these costs and seriously balance them against the true (as opposed to theoretical) benefits of more open trade regimes.

What can be done to counteract these distributional and social costs? Most economists reject out of hand any discussion of interference with the market processes of expanding trade. These economists are then typically left with a number of non-trade related policy suggestions. The first and most hopeful argument is that the profits made from those industries and sectors that benefit from expanded trade will be reinvested and create more jobs, thus absorbing into high paying jobs workers who were laid off due to offshoring and changes in trade patterns. But Milberg et. al.(this volume) show that in the U.S. increases in profits and the profit share have not led to commensurate increases in investment in recent years. Along with the evidence from Kletzer (2002) and others cited above, this suggests that the optimistic scenario is not generally prevailing.

A second possible response to the distributional and social costs associated with off-shoring losses is investment in education and retraining to allow workers to find jobs more easily in the expanding sectors. Currently the resources devoted to such retraining are woefully inadequate (eg. Kletzer and Rosen, 2005). Between 1974 and 2002, approximately 25 million workers were eligible for Trade Adjustment Assistance, the major US government policy for workers loosing their jobs due to international trade. And of these, only 2.5 million actually received assistance, mostly income assistance for up to 52 weeks beyond that available due to unemployment insurance, training and job search help. The income maintenance was on average only $\$ 200$ per week, less than half the average weekly pay in the jobs that had been lost (Kletzer and Rosen 2005, 317). It is widely understood that this program, and subsequent similar programs, like those created with the North American Free Trade Agreement (NAFTA), are completely inadequate. Yet there is little political support for a dramatic increase in resources, probably largely due to the lack of political power wielded by those who directly suffer from changing trade patterns. Only when the political power of these individuals and their communities is increased is it likely that serious and adequate support will be forthcoming. 
A more general argument favors better education as a mechanism for enhancing the ability of U.S. workers to compete in the global economy (e.g. Friedman, 2006). Blinder (2005) doubts that typical formulations of the education solution will work as suggested, as future off-shoring will not be based on education but on the degree to which jobs require personal interface. Still, most observers believe that more and better education is one of the key ways to reduce the social costs from globalization for U.S. workers. Another, related proposal is enhanced investment in infrastructure so that the United States is a more attractive and productive site for production and trade.

But even if these policies were helpful, these potential solutions are likely to fail because they are undermined by the very processes of off-shoring and globalization themselves. Off-shoring industries gain more profits but do not reinvest them domestically because globalization enhances the after-tax profitability of investment abroad rather than at home. However, these profits cannot be captured in the form of taxes to be reinvested at home because globalization allows the firms to evade or politically undermine tax enforcement; workers are not able to get sufficient adjustment assistance because their political power has been lowered relative to firms who can play off one jurisdiction against the other in the competition for investment; and education and infrastructure cannot be adequately funded because of the loss in tax revenue due, at least in part, to off-shoring and globalization. In short, globalization precludes the very solutions required to compensate for its negative impacts. This is the fundamental conundrum of off-shoring that economists have not confronted adequately.

\section{Capital Mobility and the Weakening of Sovereign Taxing Powers}

Economists have long known that increased international capital mobility might result in a reduction of nations' ability to tax corporations and other 'mobile factors of production' (Avi-Yonah 1998, Wilson 1999). If corporate taxes fell, governments would have to raise taxes on others less able to avoid these taxes, or cut expenditures or some combination of the two.

Despite the theoretical presumption of such impacts, empirical work, until recently, has found mixed evidence of a corporate tax 'race to the bottom.' Some economists have suggested that agglomeration effects - that is, the desire of corporations to invest in locations with high levels of social and physical infrastructure and to be near other firms - allows 'core countries' to attract foreign direct investment (FDI) even if they maintain high corporate tax rates. ${ }^{5}$ In this case, the race to the bottom could be attenuated or play out differently in different countries. Still, the most recent studies show that corporate tax rates have indeed fallen, as capital mobility has risen. In the OECD countries the rates fell from 40 percent in 1981 to around 28 percent in 2001. The variability across

\footnotetext{
${ }^{5}$ See Garretsen and Peeters (2006) for a recent review.
} 
countries in corporate tax rates declined as well (Garretsen and Peeters 2006, 9). ${ }^{6}$ Hines (2005) shows that between 1982 and 1999 the decline in effective tax rates on US multinational corporations was even larger that the decrease in the statutory corporate tax rates in OECD countries (see Table 2).

Table 2 about here

It is likely that these declines are at least partly due to tax competition among countries, as they vie for more FDI. Numerous studies have shown that foreign direct investment responds to lower tax rates, thereby fueling this tax competition. De Mooij and Ederveen $(2003,5)$ find that the "mean value of the tax rate elasticity... is around -3.3 , i.e., a $1 \%$ reduction in the host-country tax rate raises foreign direct investment in that country by 3.3\%." Of course, this tax competition does not only afflict nation states, but also states, provinces and regions within countries, as we discuss more fully below.

The decline in capital tax rates have also been promoted by capital exporting countries through changes in their tax and regulatory policies. Altshuler and Grubert (2005) describe the tax policy changes in the United States that have contributed to enormous losses in tax revenue due to offshore tax avoidance. In 1997, the United Treasury issued regulations that greatly simplified the use of more aggressive tax planning strategies. These allow, among other things, for the United States and a partner country to cooperate in allowing corporations to shift income to a third country, such as a tax haven, to avoid paying corporate taxes. Altshuler and Grubert $(2005,6)$ find that in 2002, for example, multinational corporations saved about $\$ 7$ billion in taxes from these more aggressive tax planning activities which is about 4 percent of FDI income and 15 percent of total host country tax burdens. They also report that during $1992-1998$ countries which had seen a decline in their shares of US foreign direct investment lowered their tax rates to attract more investment (traditional tax competition).

Recently, changes in the US tax laws have further increased the incentives for MNCs to offshore, and they are likely to drive the effective corporate tax rates even lower. The so-called American Jobs Creation Act, signed into law in October 2004, further reduces the tax burden on the foreign income of multinational firms (Clausing 2005, 5), resulting both in increased incentives for US MNCs to offshore and in lowering corporate income tax revenue in the long run.

\footnotetext{
${ }^{6}$ There are many measures of corporate tax rates used in the literature: statutory tax rates, effective marginal tax rates, and average effective tax rates. Garretsen and Peeters use average effective corporate tax rates. Using statistical analysis, they also find that the decline in corporate tax rates is associated with increases in capital mobility, though so-called agglomeration effects attenuate the negative impacts, allowing large countries more leeway in maintaining higher corporate tax rates if they choose to do so.
} 
Companies use a variety of strategies to reduce their tax liabilities, including accounting changes to shift profits to low tax areas and transfer pricing which involves setting prices for buying and selling inputs within the MNC so as to declare high profits in low tax areas. Evidently, US multinational corporations are very effective at this practice. Clausing (2005) compares the real and accounting activities of US MNCs in 2002. There is practically no overlap between the top 10 locations of US MNCs by their employment and the top 10 locations by reported income. The reason is not hard to find: the average effective tax rate is 31 percent in the top 10 locations by employment and 17 percent in the top 10 locations by reported income (See Table 3).

\section{Table 3 about here}

The use of offshore tax havens by individuals has gone up tremendously as well. Guttentag and Avi-Yonah (2006) estimate that the use of offshore tax havens by individuals cost the U.S. Treasury between $\$ 40$ billion and $\$ 70$ billion each year. The IRS further estimates that corporate offshore tax evasion in 2001 totaled about $\$ 30$ billion (Levin, 2006). But The Citizens for Tax Justice estimate that the annual loss of tax revenue is \$ 255 billion (Spencer, 2006).

\section{Aggregate Demand}

A second self-reinforcing problem associated with the current version of globalization is the lack of domestic aggregate demand. This problem has many deep and complex causes which have been discussed in detail in the literature (e.g. Crotty, Epstein, and Kelly 1998; Pollin 2003; Crotty, 2005; Baker, Epstein and Pollin, 1998). Among the key causes of this problem are the common neoliberal trifecta of fiscal austerity, anti-inflation monetary policy, and export-led trade policy. In combination, these policies export to other countries the responsibility for generating aggregate demand, while at the same time putting enormous downward pressure on domestic wages and costs. In the current environment, the United States has become the aggregate demand generator of last resort and this has put enormous pressure on domestic wages and employment in the U.S. Freeman (this volume) stresses the importance of the 'doubling' of the global labor force. The lack of widespread aggregate demand and the related focus on export-led growth means that increasing numbers of workers in the global economy are placed in increasing competition with each other. Hence, the forces we describe here intensify the negative impact this 'doubling' has on employment, wages and bargaining power for workers around the globe.

It is worth exploring a little further some of the elements of this negative aggregate demand picture. One of the factors which has worsened the global aggregate demand picture has been the increased focus on inflation targeting and other anti-inflation focused monetary policy, promoted by the IMF and many economists (Epstein, 2006). These policies represent a change from earlier central banking practice in much of the world that focused in a more balanced way on promoting employment and limiting inflation. A second factor is the promotion of 
export-led growth as a standard strategy embedded in bi-lateral trade agreements, IMF structural adjustment, poverty reduction strategy papers, and other mechanisms of neo-liberal global governance (Rodrik, 2006). These policies result in high levels of international labor market competition in a context of relatively slow global aggregate demand.

\section{Coordination Problems}

An additional factor reducing global aggregate demand in the current environment stems from the reduction in national capital controls and the accompanying lack of global regulation of destructive speculative global financial flows. In addition to generating financial crises that lead to recessions and broader crises, these factors have lead to an unprecedented build-up of foreign exchange reserves among developing countries, undertaken to self-ensure against sudden outflows of foreign or domestic capital. This enormous hording of reserves likely creates a significant drag on global aggregate demand. If there were national and/or global controls on unstable financial flows, then countries would not have to hold these excessive, costly reserves, and could spend the reserves, thereby increasing global aggregate demand (e.g. Epstein, Grabel and Jomo 2005, Rodrik, 2006).

\section{Bargaining Power}

All of these factors - tax competition, insufficient aggregate demand and coordination problems - have contributed to a dramatic decline in the bargaining power of labor in the United States and some other wealthy countries, especially in the context of the doubling of the global labor force. In the United States the decline in the bargaining power of works has been exacerbated by political changes, including changes in laws that have made it more difficult to unionize, the decline in the real minimum wage, and increased foreign competition in manufactured goods (eg. Pollin 2003, Bronfenbrenner 2000, Brown 2004, Faux 2006). This decline in bargaining power has greatly reduced the ability of U.S. workers to either reap sufficient benefits from globalization, including offshoring, or to change the laws and regulations in such a way that they could be protected from the negative impacts of these changes.

Globalization has affected wages and tax rates through threat effects as well as actual changes in the quantities of employment, goods and investment moving across borders. Bronfenbrenner (2000) shows how the threat by employers to move jobs abroad increases the likelihood of failed contract negotiations for workers and failed unionization drives. Burke and Epstein (2002) review literature that shows the powerful impact of threats by firms to locate or not in particular locations on the tax rates and subsidies by governments attempting to attract or retain jobs.

\section{Altering the Political Dynamics}


In order to alter the dynamics in such a way that workers and citizens more generally share the benefits from globalization in general and off-shoring in particular, there must be an increase in the bargaining power of the 'losers' from these processes. Below we sketch some examples of policies that could be implemented to help shift more bargaining power toward the 'losers' from globalization and off-shoring. Comprehensive discussions of these policy changes are far beyond what we can provide here; these examples are simply meant to provide a general idea of these types of policies.

\section{Taxation}

Tax reform to generate more revenue, to reduce artificial incentives for off-shoring and to reduce the bargaining advantage of corporations relative to workers and the majority of citizens needs to occur at a number of levels: changes in laws, improvements in enforcement, and improvements in tax coordination.

\section{Changes in Tax Laws}

There has been much discussion of altering the corporate income tax, including the suggestion of eliminating it altogether on the grounds that a corporate income tax cannot be maintained in a world of high capital mobility. ${ }^{7}$ With the right enforcement and tax coordination (see below), however, corporate taxes can be maintained and can help to maintain the integrity of the personal income tax. ${ }^{8}$ Some reforms could, in principle, raise significantly more revenue and reduce or even eliminate the tax incentives currently in place for off-shoring. Among the most important reforms is the elimination of deferral of U.S. taxation on un-repatriated income earned in low-tax countries. Under current U.S. corporate tax law, MNC's - for the most part - do not have to pay income tax on profits earned in foreign affiliates until they repatriate the profits to the US. With some exceptions, this allows firms to accumulate income offshore free of US income tax. This increases the value of reporting profits in low tax jurisdictions. A complete elimination of deferral would bring the US tax system closer to the ideal of capital export neutrality, as there would no longer be a tax incentive to earn income in low-tax countries or to shift profits to such locations (Clausing $2005,26)$. Some have suggested to combine this policy with a reduction the statutory tax rate to reduce the incentive for evasion, including the increasingly popular practice of corporate inversion, with US-based companies choosing to move their headquarters to locations with low tax rates.

\section{Tax Coordination}

More coordination among tax jurisdictions is needed to address the challenges of the race to the bottom competition, i.e. to reduce the pressures for excessive reductions in tax rates or increases in subsidies. This coordination is often necessary at the international as well as the domestic level. Below we discuss efforts to share information to improve enforcement. Here, it is important

\footnotetext{
${ }^{7}$ See, for example, Clausing (2005) for a discussion.

${ }^{8}$ In the absence of a corporation income tax, wealthy individuals can shift income to corporations and thereby avoid the personal income tax as well (Clausing, 2005).
} 
to note efforts to harmonize tax rates in the European Union, for example. Such efforts should be extended to larger groups of countries. Vito Tanzi (1999) has proposed an international tax authority to strengthen international coordination of tax rates and enforcement significantly. Undoubtedly, there are many practical objections to such a scheme, but serious consideration is warranted, given the seriousness of the tax problems facing many countries around the world as a result of globalization.

Problems of tax competition arise not only at the national level. In the United States, there is a 'war among the states' to attract investment from both domestic and foreign capitalists. In a recent survey Timothy Bartik $(2004,11)$ concludes that many incentives currently offered in the United States have costs that exceed benefits, often costing upwards of $\$ 140,000$ per job created in terms of lost revenue. Among the proposals to eliminate wasteful inter-state competition for investment is a ban on such competition among the 50 states in the US. (Holmes 1995). Short of outlawing such incentives, other proposals include making the incentives transparent (now it is often impossible for the public to know what subsidies are being given and under what conditions); performance requirements to hire a certain number of workers, including local workers; claw-back provisions so that the subsidies must be returned if the conditions are not met; and the creation of an over-all budget constraint to limit the number of incentives. A particularly important feature of a reformed incentive structure would be to focus the hiring on the unemployed, thereby increasing labor demand for the local unemployed or underemployed (Bartik, 2004, 32).

\section{Enforcement}

On the enforcement front, Avi-Yonah $(2006,2)$ describes the challenge succinctly: "Simply put, we have the technology which enables people to conduct their affairs without regard to national borders and without transparency, while restricting tax collectors to geographic borders..." He recommends a number of steps to address offshore tax abuses, including an increase in IRS enforcement to close the international tax gap; more bilateral information exchange, in particular the adoption of the new OECD exchange of information rules which makes exchange of information on civil as well as criminal tax liabilities mandatory, does not require dual criminality or suspicion of a crime other than tax evasion, and overrides bank secrecy provisions of domestic laws; and the imposition of sanctions on non-cooperating tax havens, including denying portfolio interest exemption to countries that do not provide adequate exchange of information.

\section{Aggregate Demand}

A great deal of research has suggested policy reforms that could take place at international, regional and national levels to reverse the common focus of fiscal and monetary policy on austerity and inflation reduction, and to reduce the international financial instability that leads to demand-reducing crises or policies to avoid crises, such as the promotion of export led growth and the accumulation of resulting hard-currency reserves. 
In the US, central bank policy should take seriously the Humphrey Hawkins bill which requires the Federal Reserve to maintain both full employment and price stability. Abroad, countries should strongly consider abandoning inflation- targeting approaches to central bank policy and adopt policies that promote other domestic goals such as more employment generation, higher investment rates, or more stable and competitive exchange rates, along with moderate inflation rates. ${ }^{9}$ Both domestic and international reforms need to be implemented to reduce the costly and contractionary policies of excessive foreign exchange accumulation occurring in many developing countries. The implementation of domestic capital controls, and capital management techniques more generally, can reduce the unstable inflows and outflows of capital that have contributed to the need to accumulate more reserves (Epstein, Grabel and Jomo, 2005; Grabel, 2005).

A variety of reforms should be considered at the international level to reduce excessive, pro-cyclical and short term speculation. These could include, for example, a so-called Tobin Tax - a small tax on all foreign exchange transactions. At a regional level, reserve pooling schemes could be created to allow more reinvestment of reserves into local development projects that could help domestically-oriented industries and generate more employment.

\section{Getting There from Here: Bargaining Power and Economic Reform}

\section{Bargaining Power}

Enhancing the bargaining power of workers and citizens vis-a-vis mobile corporations will be necessary to bring about long-lasting reforms in domestic and international institutions and policies to insure that benefits from global integration are more widely shared. Tax changes like the ones described above can preserve government revenue which can be used to improve infrastructure and the educational qualifications of US workers so that they can better compete for high quality jobs and pay. Policies to increase aggregate demand can enhance workers' incomes. Bernstein and Baker (2003), for example, find that during the boom of the later Clinton years, reductions in unemployment had a significant impact on the ability of workers to bargain for higher wages, particularly for those at the low levels of the wage ladder. More generally, extensive empirical work on the 'wage-curve' in different countries suggests that reductions in local unemployment rates have a significant positive impact on real wages, presumably at least partly through the bargaining channel (Blanchflower and Oswald, 2005). ${ }^{10}$

\footnotetext{
${ }^{9}$ See Epstein, (2006) and Pollin, et. al (2006) for an application of this approach to the case of South Africa.

${ }^{10}$ Blanchflower and Oswald (2005) report that a large number of studies from different countries including the U.S. suggest that the elasticity of real wages with respect to the unemployment rate is approximately 0.1, implying that a doubling of the unemployment rate is associated with a ten percent decline in the level of real wages (p. 1).
} 
Other policies that increase the bargaining power of workers include increases in minimum wages and living wages (Pollin 2003; Pollin, et. al. forthcoming). Other possible labor market policies would include pre-identifying industries and provide trade adjustment assistance to all workers laid off in these industries, independently of whether unemployment was due to international trade, and extending wage insurance programs to help workers recoup lost wages if they are laid off and cannot find a job that pays as much as their previous job (Kletzer and Rosen, 2005). Bernstein (2006) proposes more public employment programs to provide employment, skill training, and needed infrastructure. All of these programs would directly increase the income or reduce the instability of income for workers. And they and would indirectly enhance workers' bargaining power making it more likely that they can push back against corporations both at the bargaining table and in the political sphere.

\section{A Paradox}

A fundamental paradox in this argument will not have escaped most readers. We need changes in policies and institutions to give workers and citizens the bargaining power that will induce governments to govern off-shoring and capital mobility so that there will be widely shared benefits; but only when citizens and workers have more bargaining power will these policy changes actually come about. This is the proverbial chicken and egg problem, or the "you can't get there from here" conundrum. What is to be done?

\section{Threat Effects in Reverse}

One way to answer this question is to look at how such changes occurred in the recent past. Kletzer and Rosen (2005) report, for example, that laws to implement and improve Trade Adjustment Assistance have only been passed when the President was trying to get Congress to pass a trade deal. The threat by congress NOT to pass the trade agreement leads supporters of trade agreements to make concessions on more labor-friendly policies. This experience suggests the key: threats to refuse to pursue future agreements, or even to reverse previous agreements on trade such as the WTO agreement, bi-lateral trade agreements, and NAFTA could bring about significant changes along the lines we have described, if these threats are credible. ${ }^{11}$

More specifically, proponents of a more efficient and equitable approach to off-shoring and globalization more generally in the U.S. should support a moratorium on all future trade and investment agreements until solutions are implemented to the taxation, social investment and aggregate demand problems we have identified. In short, the presumption should be that globalization should

\footnotetext{
${ }^{11}$ Crotty and Epstein (1996) argued in a different context that capital controls, or the threat of imposing them, could be helpful, or even necessary to convince firms to pursue more socially desirable behaviors, such as paying more taxes, increasing domestic investment, and generating more employment. As long as firms knew they always had an exit strategy, then it would be difficult for the government to gain the bargaining power necessary to win concessions from firms.
} 
NOT be allowed to undermine the bargaining power of citizens or the social investments of society. And until globalization can proceed without doing so, future movement in that direction should be reduced.

Recently, the consensus among US elites in favor of more trade agreements has been showing signs of cracking. The 2006 congressional elections, which elected trade policy critics such as Sherrod Brown (Brown, 2004) to the Senate reflects this sagging consensus. Supporters of more trade liberalization decry this shift in sentiment. They maintain that trade liberalization is better for society as a whole, and 'we' can make the outcomes fair by having the winners simply compensate the losers.

But, in our view, this is an illusion. In a world where allocation, distribution and power are as inextricably linked as they are in the areas of trade and off-shoring, the separation of these policies into neat, separate piles called 'allocation' and 'distribution' will simply not work. Economists can convince themselves that they can talk about the efficiency of off-shoring and then, as an afterthought, describe a re-distributional package. But if the new political economy has taught us anything, it is that this artificial separation is wishful thinking at best, and it, more likely, contains a heavy dose of self-delusion. A healthy skepticism about the merits of more trade liberalization, and threats to reverse these trade agreements is a good exercise in our democracy, if it is accompanied by realistic, well thought-out policies to allow us to capture the benefits of more trade and off-shoring, and use those benefits to re-invest into our society, making sure that the benefits are widely shared. 
Table 1: Employment change and import ratio of produced inputs, 1998 - 2003.

\begin{tabular}{|c|c|c|c|c|}
\hline Industry & $\begin{array}{c}\text { Employment } \\
\text { Change, } \\
\text { thousands, } \\
\text { 1998-2003 }\end{array}$ & $\begin{array}{l}\text { Employment } \\
\text { Change, \%, } \\
\text { 1998-2003 }\end{array}$ & $\begin{array}{l}\text { Imports Share } \\
\text { of Inputs, } \\
2003\end{array}$ & $\begin{array}{c}\text { Imports Share } \\
\text { of Inputs } \\
\text { Change, } \\
\text { 1998-2003 }\end{array}$ \\
\hline Apparel and leather and allied products & -342.9 & $-50.3 \%$ & $64.0 \%$ & $9.7 \%$ \\
\hline Textile mills and textile product mills & -211.7 & $-33.6 \%$ & $23.0 \%$ & $8.0 \%$ \\
\hline Computer and electronic products & -474.3 & $-26.4 \%$ & $39.4 \%$ & $3.1 \%$ \\
\hline Primary metals & -166.5 & $-26.3 \%$ & $21.3 \%$ & $0.6 \%$ \\
\hline Machinery & -357.1 & $-24.0 \%$ & $29.4 \%$ & $3.8 \%$ \\
\hline $\begin{array}{l}\text { Electrical equipment, appliances, and } \\
\text { components }\end{array}$ & -140.2 & $-23.8 \%$ & $34.7 \%$ & $9.6 \%$ \\
\hline Other transportation equipment & -160.5 & $-19.9 \%$ & $19.9 \%$ & $0.3 \%$ \\
\hline Paper products & -115.8 & $-18.7 \%$ & $12.1 \%$ & $1.1 \%$ \\
\hline Printing and related support activities & -151.6 & $-18.4 \%$ & $3.5 \%$ & $1.2 \%$ \\
\hline Petroleum and coal products & -21.3 & $-16.1 \%$ & $13.0 \%$ & $3.8 \%$ \\
\hline Fabricated metal products & -261.3 & $-15.1 \%$ & $12.5 \%$ & $3.0 \%$ \\
\hline Plastics and rubber products & -135.1 & $-14.4 \%$ & $12.2 \%$ & $2.0 \%$ \\
\hline $\begin{array}{l}\text { Motor vehicles, bodies and trailers, } \\
\text { and parts }\end{array}$ & -177.2 & $-13.6 \%$ & $35.4 \%$ & $8.7 \%$ \\
\hline Furniture and related products & -81.8 & $-12.6 \%$ & $25.0 \%$ & $9.9 \%$ \\
\hline Wood products & -74.6 & $-12.1 \%$ & $16.6 \%$ & $2.5 \%$ \\
\hline Miscellaneous manufacturing & -73.5 & $-10.1 \%$ & $35.5 \%$ & $3.3 \%$ \\
\hline Chemical products & -97.8 & $-9.9 \%$ & $23.4 \%$ & $6.1 \%$ \\
\hline Nonmetallic mineral products & -47.8 & $-8.9 \%$ & $16.5 \%$ & $3.9 \%$ \\
\hline $\begin{array}{l}\text { Food and beverage and tobacco } \\
\text { products }\end{array}$ & -61.3 & $-3.5 \%$ & $7.7 \%$ & $1.8 \%$ \\
\hline
\end{tabular}

Source: Authors’ calculations. 
Table 2: Statutory and Effective Corporate Tax Rates (\%)

\begin{tabular}{c|cc}
\hline \multicolumn{2}{c}{1982} & 1999 \\
\hline $\begin{array}{c}\text { Statutory Corporate Tax } \\
\text { Rates: }\end{array}$ & & \\
Average, weighted by \\
GDP & 45.9 & 32.9 \\
Un-weighted Average & 41.3 & 32.0 \\
\hline $\begin{array}{c}\text { Effective Corporate Tax } \\
\text { on U.S. Multinationals: }\end{array}$ & & 26.2 \\
$\begin{array}{c}\text { Average Weighted by } \\
\text { GDP }\end{array}$ & 42.6 & 23.9 \\
Un-weighted world \\
Average
\end{tabular}

Note: The table presents information for matched samples of 68 countries in 1982 and 1999 with respect to statutory rates and 45 countries with respect to average effective corporate tax rates.

Source: James R. Hines, Jr. "Corporate Taxation and International Competition", University of Michigan Ross School of Business, Working Paper No. 1026, July, 2005, p. 29. 
Table 3: Top Employment and Top Income Countries Reported By U.S. Multinational Companies, 2002

\begin{tabular}{lr|lr}
\hline $\begin{array}{l}\text { Top } \\
\text { Employment } \\
\text { Countries }\end{array}$ & $\begin{array}{r}\text { Effective } \\
\text { Tax Rate } \\
(\mathbf{\% )}\end{array}$ & $\begin{array}{l}\text { Top Income } \\
\text { Countries }\end{array}$ & $\begin{array}{r}\text { Effective } \\
\text { Tax Rate } \\
\text { (\%) }\end{array}$ \\
U.K & 31 & Ireland & 8 \\
Canada & 26 & Bermuda & 2 \\
Mexico & 37 & Netherlands & 9 \\
Germany & 27 & U.K. & 31 \\
France & 34 & Canada & 26 \\
Brazil & 100 & Luxembourg & 1 \\
China & 17 & Switzerland & 4 \\
Australia & 29 & Japan & 39 \\
Japan & 39 & Mexico & 37 \\
Italy & 41 & Singapore & 11 \\
& & & \\
Average* & $\mathbf{3 1}$ & Average & $\mathbf{1 7}$ \\
\hline
\end{tabular}

Notes: Effective tax rates are calculated as foreign taxes paid by U.S. affiliate firms in a given country relative to net (pre-tax) income.

The average is calculated without Brazil's rate which is greater than $100 \%$ due to highly idiosyncratic factors.

Source: Kimberly A. Clausing, "The Role of U.S. Tax Policy in Offshoring", Reed College, June, 2005. 


\section{Bibliography}

Altshuler, Rosanne, Harry Grubert. 2005. The Three Parties in the Race to the Bottom: Host Governments, Home Governments and Multinational Companies.CESIFO Working Paper No. 1613, December.

Avi-Yonah, Reuven S., 1998. Globalization, Tax Competition and the Fiscal Crisis of the State, manuscript, Havard Law School.

Avi-Yonah, Reuven S. 2006. Prepared Testimony Before U.S. Senate Permanent Subcommittee on Investigations Hearing on Offshore Transactions, August 1.

Baker, Dean, Gerald Epstein and Robert Pollin, eds.1998. Globalization and Progressive Economic Policy, Cambridge: Cambridge University Press.

Bartik, Timothy J. 2004. Incentive Solutions. Upjohn Institute Staff Working Paper, No. 04-99.

Bernstein, Jared. 2006. All Together Now; Common Sense for a Fair Economy. San Francisco: Barrett-Koehler Publishers, Inc.

Bernstein, Jared and Dean Baker. 2003. The Benefits of Full Employment; When Markets Work for People. Washington: Economic Policy Institute.

Blanchflower, David. G. and Andrew J. Oswald, 2005. The Wage Curve Reloaded. NBER Working Paper, No. 11338, May.

Blinder, Alan S. 2005. Fear of Off-shoring. Princeton University: CEPS Working Paper, No. 119.

Bronfenbrenner, Kate, 2000. "Uneasy Terrain: The Impact of Capital Mobility on Workers, Wages and Union Organizing". Report to The U.S. Trade Deficit Review Commission. mimeo. Cornell University.

Brown, Sherrod. 2004. The Myth of Free Trade; Why American Trade Policy Has Failed. New York: New Press.

Burke, James, 1997. “The Effects of Foreign Direct Investment on Investment, Employment and Wages In the United States”. mimeo. Department of Economics, University of Massachusetts, Amherst.

Burke, James and Gerald Epstein. 2002. Threat Effects and the Internationalization of Production". In Jayati Ghosh and C.P. Chandrasekhar, eds. 
Work and Well-Being in the Age of Finance. New Delhi: Tulika Books.

Burke, James and Gerald Epstein. 2006. Employment Losses in US Manufacturing, 1987 - 2003. Political Economy Research Institute, Working Paper, www.peri.umass.edu .

Campa, Jose and Linda Goldberg. 1997. The Evolving External Orientation of Manufacturing Industries: Evidence from Four Countries. National Bureau of Economic Research Working Paper, No. 5919.

Clausing, Kimberly. 2005. The Role of U.S. Tax Policy in Off-shoring. Reed College.

Crotty, James and Gerald Epstein. 1996."In Defense of Capital Controls", London: Socialist Register.

Crotty, James. 2005. "The Neo-Liberal Paradox: The Impact of Destructive Product Market Competition and Modern Financial Markets on Non-Financial Corporation Performance in the Neo-Liberal Era", in Epstein, ed., 2005, Financialization and the World Economy. Northampton, MA.: E. Elgar Publishers, pp. $77-110$.

Crotty, James, Gerald Epstein, and Patricia Kelly 1998. "Multinational Corporations in the Neo-Liberal Regime,” in Dean Baker, Epstein and Pollin, eds. Globalization and Progressive Economic Policy. Cambridge: Cambridge University Press.

Epstein, Gerald. 2004. Alternatives to Inflation Targeting Monetary Policy. www.peri.umass.edu .

Epstein, Gerald. 2005a. Financialization and the World Economy. Northampton: Edward Elgar.

Epstein, Gerald. 2005b. Capital Flight and Capital Controls in Developing Countries. Northampton: Edward Elgar.

Epstein, Gerald. 2006. Central Banks as Agents of Economic Development. www.peri.umass.edu

Epstein, Gerald, Ilene Grabel, and Jomo K.S., 2005. "Capital Management Techniques in Developing Countries", in Epstein, 2005b.

Faux, Jeff. 2006. The Global Class War; How America's Bipartisan Elite Lost Our Future and What It Will Take to Win It Back? New York: John Wiley. 
Federal Reserve Bank of Minneapolis, 1994. "Congress Should End the Economic War Among the States,” http://woodrow.mpls.frb.fed.us/sylloge/econwar/war-cite.html

Feenstra, Robert C. (ed). 2000. The Impact of International Trade On Wages. Chicago: The University of Chicago Press.

Feenstra, Robert and Gordon Hanson. 1999. "The Impact of Outsourcing and High-Technology Capital on Wages: Estimates for the United States, 1979-1990," Quarterly Journal of Economics, 114(3): 907-940.

Friedman, Thomas. 2005. The World is Flat. New York: Farrar, Straus and Giroux.

Garretsen, Harry and Jolanda Peeters, Capital Mobility, Agglomeration and Corporate Tax Rates: Is the Race to the Bottom for Real? De Nederlandsche Bank NV Working Paper No. 113/2006.

Guttentag, Joseph and Reuven Avi-Yonah. 2006. "Closing the International Tax Gap" in Max B. Sawicky, ed. Bridging The Tax Gap: Addressing the Crisis in Federal Tax Administration. Washington: Economic Policy Institute.

Harrison, Ann E. and Margaret S. McMillan. 2006. Outsourcing Jobs?

Multinationals and US Employment. NBER Working Paper, No. 12372, July.

Hines, James R. Jr. 2005. Corporate Taxation and International Competition. Ross School of Business Working Paper No. 1026. July.

Holmes, Thomas J. 1995, “Analyzing a Proposal to Ban State Tax Breaks to Businesses,” Federal Reserve Bank of Minneapolis Quarterly Review, pp. 29-39.

Kletzer, Lori G. 2002. Imports, Exports and Jobs: What Does Trade Mean for Employment Job Loss? Kalamazoo, MI: W.E. Upjohn Institute for Employment Research.

Kletzer, Lori G. and Howard Rosen, 2005, "Easing the Adjustment Burden on US Workers" in C. Fred Bergsten, The United States and the World Economy; Foreign Economic Policy for the Next Decade, pp. 313 - 341.

Levin, Carl, Senator. 2006. Statement on "Hearing on Deconstructing the Tax Code: Uncollected Taxes and Issues of Transparency". U.S. Senate. September 26.

Mankiw, N. Gregory and Philip Swagel. 2006. The Politics and Economics of Offshore Outsourcing. NBER Working Paper, No. 12398. July. 
Mooij, R. de and S. Ederveen. 2003. "Taxation and Foreign Direct Investment: A Synthesis of Empirical Research". International Tax and Public Finance, Vol. 10, No. 6, November, pp. 673-693.

Pollin, Robert. 2003. Contours of Descent. New York: Verso Press.

Pollin, Robert, Mark Brenner, Stephanie Luce and Jeannette Wicks-Lim. Forthcoming. A Measure of Fairness: The Economics of Living Wages and Minimum Wages in the United States. Ithaca, New York: Cornell University Press.

Rodrik, Dani. 1997. Has Globalization Gone Too Far? Washington: Institute for International Economics.

Rodrik, Dani. 2006. The Social Cost of Foreign Exchange Reserves. Harvard Economics Department Working Papers.

Sawicky, Max. 2006. Bridging the Tax Gap. Washington: Economic Policy Institute.

Spencer, David. 2006. "The Cost of Capital Flight". Accountancy Business and the Public Interest, Vol. 4., No. 2.

Tanzi, Vito, 1995. Taxation in an Integrating World. Washington: Brookings Institution.

Uchitelle, Louis. 2006. The Disposable American; Layoffs and Their Consequences. New York: Alfred A. Knopf.

Wilson, John D. 1999. "Theories of Tax Competition”, National Tax Journal, June, Vol LII, No. 2., pp. 269-303. 